\title{
Platinum Complexes \\ with Bioactive Nitroxyl Radicals: \\ Synthesis and Antitumor Properties
}

\author{
Vasily D. Sen', Alexei A. Terentiev and Nina P. Konovalova
}

Additional information is available at the end of the chapter

http://dx.doi.org/10.5772/39113

\section{Introduction}

Nitroxyl radicals (NRs), which are sometimes called "organic nitrogen oxides" exhibit a wide range of biological activities, e.g., hemodynamic effect, protection against ionizing radiation, suppression of oxidative stress in different types of pathology (Soule et al., 2007; Wilcox, 2010). Already in early studies of the simplest NRs, their antitumor activity was demonstrated on a model tumor, leukemia La (Konovalova et al., 1964) and their cytotoxicity was shown for HeLa cells (Klimek, 1966). Subsequent studies included: 1) indepth studies of antitumor activity of simple NRs (TEMPOL, TEMPO), 2) trials of therapeutical efficiency of NRs used in combination with the clinically approved anticancer drugs, and 3) synthesis and studies of hybrid compounds with NRs covalently bound to anticancer pharmacophores. Recent studies have shown that simple nitroxyls affect the cell viability through a redox-mediated signaling and induce a multifactor cell death response, including oxidative damage, cell cycle arrest and apoptosis (Gariboldi et al., 1998; 2000; 2003; Suy et al., 2005).

Nitroxide TEMPOL potentiates the cytotoxicity of doxorubicin in the culture of tumor cells with multidrug resistance (Gariboldi et al., 2006), and reduces its cardiotoxicity in rats (Monti et al, 1996). Combinations of low doses of nitroxyl TEMPO and doxorubicin or mitoxantrone exhibit additive or synergistic cytotoxicity, depending on the type of the tumor cells (Suy et al., 2005). In experiments on mice, nitroxyls at low doses $(0.25-10 \mathrm{mg} / \mathrm{kg}$ ) were shown to decrease toxicity of anticancer drugs substantially (Konovalova et al., 1991).

A considerable amount of research has been carried out on hybrid compounds containing NRs linked covalently to an anticancer pharmacophore. Nitroxyl derivatives of (thio)phosphamides (Shapiro et al., 1971; Emanuel et al., 1976; Sosnovsky \& Paul, 1984; 
Sosnovsky \& Li, 1985a), cyclophosphamide (Tsui et al., 1982), actinomycin D (Sinha et al., 1979), ethylenimino triazines (Emanuel \& Konovalova, 1992), nitrosoureas (Raikov et al., 1985; Sosnovsky \& Li, 1985b; Emanuel et al., 1986; Sen', 1993), 5-fluorouracil (Emanuel et al., 1985; Sen' et al., 1989), daunorubicin (Emanuel et al., 1982) were synthesized and studied. In comparison with the parent compounds, nitroxyl derivatives of the cytostatic drugs possess lower overall toxicity in animal studies and higher values of the half inhibitory concentrations $\mathrm{IC}_{50}$ in cell cultures. At the same time, they exhibit higher chemotherapeutic indexes (are effective in a wider range of doses) and, in the cases studied, are characterized by fewer side effects. For example, ruboxyl, a nitroxyl derivative of daunorubicin, is 8-fold less toxic to mice than the parent compound. At optimal doses, ruboxyl is more effective in experimental animal tumors and has no cardiotoxicity (Emanuel et al., 1982, 1992). After a successful phase II clinical trials (1991), its further study was interrupted due to financial problems.

Over the past 30 years, platinum complexes occupy leading positions among drugs for cancer chemotherapy. The antitumor activity of cisplatin (CP) was discovered in 1960s, and in 1978 it was approved for clinical use (Kelland, 2007). The subsequent search for improved cisplatin analogues resulted in introduction of carboplatin (1989) and oxaliplatin (2002) into clinical practice. About 15 other complexes, for various reasons, have been rejected in clinical trials. Currently, JM216 (satraplatin), picoplatin, and nanopolymer ProLindac, bearing the oxaliplatin moiety, are subject to clinical trials (Wheate et al., 2010) (Fig. 1).

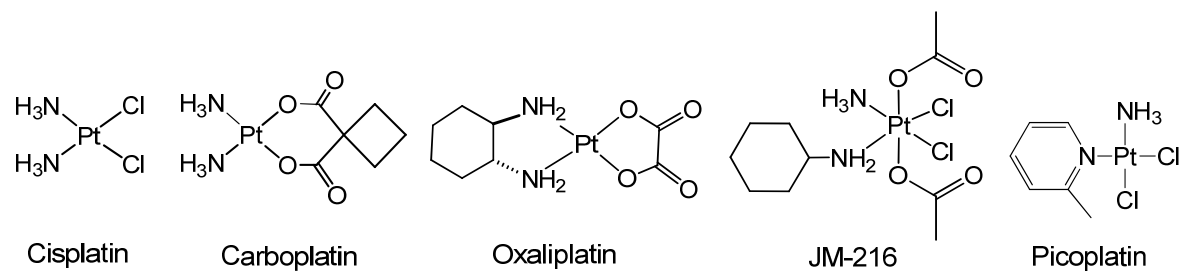

Figure 1. Platinum anticancer drugs which are in clinical use and undergoing clinical trials.

Cisplatin and other bivalent platinum complexes are effective against a number of human tumors. They are used in almost half of the treatment regimes in combinations with other anticancer drugs (Wheate et al., 2010). Complexes of bivalent platinum are highly reactive and, therefore, they are highly toxic drugs. To avoid acute toxicity, cisplatin is administered by continuous infusion of a very dilute solution (Blokhin \& Perevodchikova, 1984). Another disadvantage of cisplatin is a rapid development of tumor resistance to this drug (Koeberle et al., 2010).

Complexes of $\mathrm{Pt}(\mathrm{IV})$, being chemically more inert than $\mathrm{Pt}(\mathrm{II})$ complexes, are characterized by moderate toxicity, and are suitable for oral administration. Complexes like satraplatin can pass through the digestive tract where they are absorbed into the bloodstream. With the bloodstream they reach organs and tissues, interact with cellular targets, and thus provide an antitumor effect (Kelland, 1999). Complexes of $\mathrm{Pt}(\mathrm{IV})$ are prodrugs (drug precursors) that, after entering into the cell or on the way to it, are reduced to corresponding active $\mathrm{Pt}(\mathrm{II})$ derivatives causing cytotoxic effect. At the same time, $\mathrm{Pt}(\mathrm{IV})$ complexes are potent inhibitors 
of proliferation of tumor cells including those resistant to cisplatin. Recent advances in the study of anticancer platinum amino complexes are summarized in a number of reviews (Kelland, 2007; Wheate et al., 2010; Klein \& Hambley, 2009; Koeberle et al., 2010; Bonetti et al., 2009).

This review focuses mainly on the authors' data on synthesis and studies of new highly active platinum compounds with low toxicity, viz, $\mathrm{Pt}(\mathrm{II})$ and $\mathrm{Pt}(\mathrm{IV})$ complexes with biologically active aminonitroxyl radicals. In addition to biological activity, the advantage of such compounds is their paramagnetism which gives an opportunity to use them as spin labels in the study of the mechanism of antitumor action. The work involved the synthesis of platinum-nitroxyl complexes (PNCs), studies of their structure, physico-chemical properties and interactions with the main target, DNA. Studies of cytotoxic properties of PNCs, their impact on cell cycle and cell death were carried out using in vitro cultured tumor cells. Studies of antitumor activity, development of the tumor resistance, and synergistic antitumor effects of combinations of new complexes with cisplatin were performed in animal model tumor leukemia P388.

\section{Synthesis of PNCs}

\subsection{Pt(II) complexes}

Most of platinum complexes with high antitumor activity are non-ionic compounds with the cis-arrangement of the amino ligands (Hambley, 1997) (Fig. 1). Synthesis of complexes with two identical amino ligands or one diamino ligand is similar to the synthesis of cisplatin and is generally outlined in Fig. 2.

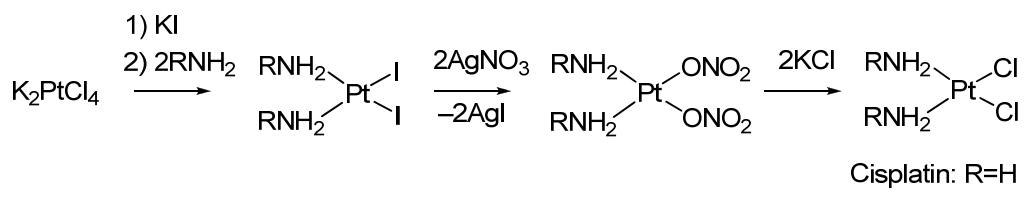

Figure 2. Synthesis of $\mathrm{Pt}(\mathrm{II})$ cis-diamino complexes.

To achieve good yields, diiodo complexes cis- $\left[\mathrm{Pt}\left(\mathrm{RNH}_{2}\right)_{2} \mathrm{I}_{2}\right]$ were prepared in the first step of the synthesis. The diiodo complexes were then converted to the target complexes by exchange reaction via water soluble dinitrato complexes (Fig. 2) (Dhara, 1970).

Complexes with two bulky amino ligands, such as compounds 1 (see Fig. 4), poorly bind to the DNA target (Section 3). Presumably, this is the main cause of their weak antitumor activity. The search for the active complexes led to the development of synthesis of mixedligand cis-diamino complexes containing only one bulky aminoligand (Giandomenico et al., 1995). The key intermediate in this synthesis is the salt $\mathrm{K}\left[\mathrm{Pt}\left(\mathrm{NH}_{3}\right) \mathrm{Cl}_{3}\right]$, which can be obtained in several ways (Oksanen \& Leskela, 1994; Oksanen, 1997; Potucka et al., 2011). The described method (Giandomenico et al., 1995) was modified by us for the preparation of PNCs with general formulae 2 and 3 (Fig. 3, 4). 


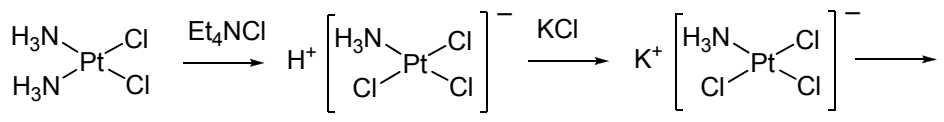
1) $\mathrm{KI}$

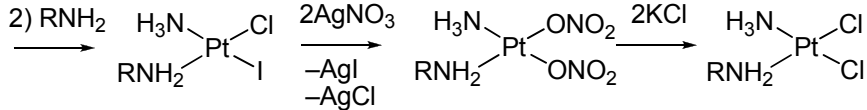

Figure 3. Synthesis of mixed amine complexes of platinum (II) (R - nitroxyl radical).

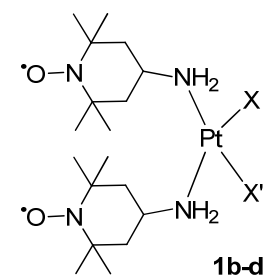

$1 b-d$<smiles>[X][R]([X])(N)NC1CC(C)(C)N([O])C1(C)C</smiles>

2a,b<smiles>[X][R]([X])(N)NC(C)(C)C1CC(C)(C)N(OC)C(C)(C)C1</smiles>

3 na-c<smiles>[X][R]([X])(N)N[C@H]1CC(C)(C)N([O-])C1(C)C</smiles>

4b-e<smiles>[X][R]([X])([X])N[C@H]1CC(C)(C)N([O])C1(C)C</smiles>

$5 b$ a $\mathrm{X}=\mathrm{Cl}, \mathrm{X}^{\prime}=\mathrm{I} ; \quad$ b $\mathrm{X}=\mathrm{X}^{\prime}=\mathrm{Cl} ; \quad$ c $\mathrm{X}=\mathrm{X}^{\prime}=\mathrm{NO}_{3}$;<smiles></smiles>

$\mathbf{n}=0-2$

Figure 4. Platinum(II) amino nitroxyl complexes.

The formulae of complexes obtained are shown in Fig. 4 (Sen' et al., 1996, 1998, 2000). Two biradical complexes of type 1 were synthesized previously (Mathew et al., 1979; Claycamp et al., 1986). For the preparation of compounds of general formula 4, which are structural analogues of oxaliplatin, we synthesized the first nitroxyl with two vicinal amino groups, trans-3,4-diamino-2,2,6,6-tetramethylpiperidine-1-oxyl (Sen', 1989). Binuclear complex 5b was also obtained based on this radical.

\section{2. $\operatorname{Pt}(I V)$ complexes}

Complexes of $\mathrm{Pt}(\mathrm{IV})$ with mixed amino ligands can be obtained only by oxidation of the $\mathrm{Pt}(\mathrm{II})$ precursors. According to the published method (Giandomenico et al., 1995), the starting $\mathrm{Pt}(\mathrm{II})$ complexes 6 are oxidized with an excess of $\mathrm{H}_{2} \mathrm{O}_{2}$ under relatively harsh conditions $\left(70{ }^{\circ} \mathrm{C}, \geq 2 \mathrm{~h}\right.$ ). Under these conditions, the oxidation of $\mathrm{Pt}(\mathrm{II})$-nitroxyl complexes leads to the formation of significant amount of by-products, probably as a result of oxidation of nitroxyl radical by $\mathrm{Pt}(\mathrm{IV})$ at elevated temperature. We found that catalytic amounts of salts of tungstic acid strongly accelerate the reaction so that preparative oxidation under mild conditions $\left(0-20^{\circ} \mathrm{C}\right)$ is limited only by the rate of dissolution of the starting complex and takes from 0.5 to 2.5 hours. 


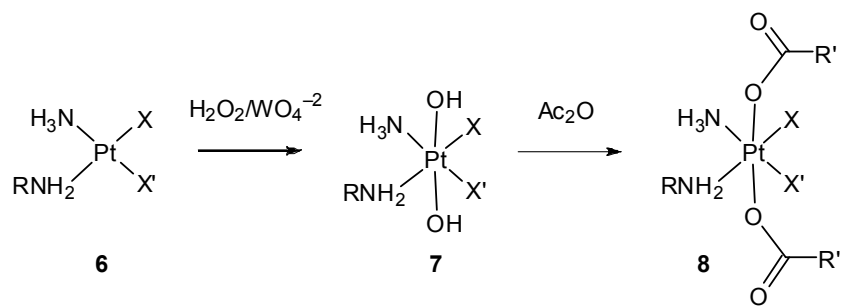

Figure 5. Synthesis of platinum(IV) complexes, R - nitroxyl radical, R '- carboxylic acid residue.

This significantly increases the reaction selectivity and the yield of the target products. transDihydroxo complexes 7 resulted from the oxidation are of interest themselves. Their acylation with organic acid anhydrides leads to the trans-dicarboxylate derivatives 8 (Fig. 5) (Sen' et al., 2003, 2006).

The method described allows one to introduce different amines and exchange the so-called leaving X-ligands at the step of preparation of $\mathrm{Pt}(\mathrm{II})$ complexes (Fig. 3) and incorporate various carboxylate ligands with the alkyl residue R' of different length at the final step (Fig. 5). Thus, we can obtain the amino complexes of $\mathrm{Pt}(\mathrm{IV})$, which differ in chemical activity, solubility in water and aqueous-lipid distribution. The formulae of $\mathrm{Pt}(\mathrm{IV})$ complexes are shown in Fig. 6.

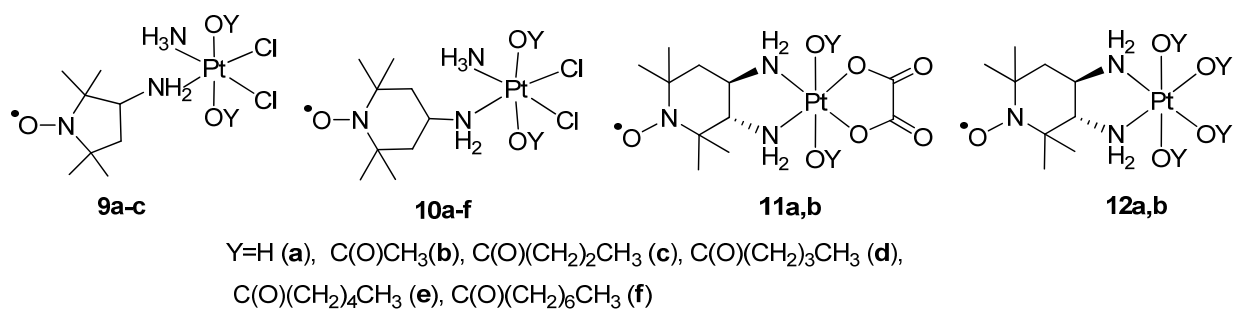

Figure 6. Platinum(IV) amino nitroxyl complexes.

The structure of PNCs was proved by elemental analysis and spectroscopic data (Sen' et al., 1996, 1998, 2000, 2003, 2006). For complexes 2b, 4d, and 10a, the structures are determined by X-ray crystallography (Sen' et al., 2000, 2003; Chekhlov, 2005).

\section{Interaction of PNCs with DNA}

Reactivity of $\mathrm{Pt}(\mathrm{II})$ diamine complexes 4 depends strongly on the nature of leaving $\mathrm{X}$ ligands. Pseudo-monomolecular rate constants for X-ligands hydrolysis in complexes $4 \mathbf{c}, \mathbf{4 d}$, cisplatin, and $4 \mathrm{e}$ at $25{ }^{\circ} \mathrm{C}$ in $0.08 \mathrm{M} \mathrm{NaOH}$ are $>10^{-2}, 1.2 \cdot 10^{-4}, 1.9 \cdot 10^{-5}$, and $2.9 \cdot 10^{-7} \mathrm{~s}^{-1}$, respectively, i.e., differ by five orders of magnitude (Shugalii et al., 1998). Therefore, the reaction of complexes with $\mathrm{S}$ - or $\mathrm{N}$-donor groups can proceed either through the step of preliminary hydrolysis with the formation of an active intermediate aqua complex (Fig. 7, path $A$ ), or by the direct substitution of the X-ligands (path $B$ ). 
Path $A$

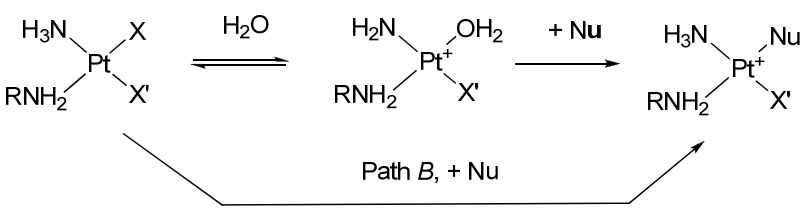

Figure 7. Reaction of $\mathrm{Pt}(\mathrm{II})$ complexes with nucleophilic atom $\mathrm{Nu}$ of a target molecule.

For relatively easily hydrolyzable complexes, including cisplatin, the reaction proceeds through the path $A$ (Alderden et al., 2006), but for complexes of type $4 \mathbf{e}\left(\mathrm{X}+\mathrm{X}^{\prime}=\right.$ cyclobutane dicarboxylate) there is an evidence for direct substitution of the $\mathrm{X}$-ligands by $\mathrm{N}$-donor groups (Frey, 1993).

It is known that cisplatin and its analogues bind mainly to the guanine and adenine bases of DNA with the formation of cross-links, thus perturbing the structure of DNA (Kelland, 2007; Wheate et al., 2010). Analysis of the EPR spectra of DNA modified with PNCs, together with hydrolytic determination of platinated DNA bases, showed (Shugalii et al., 1998 ) that complexes $\mathbf{3 0}$ b and $\mathbf{4 d}$ form predominantly ( $\geq 95 \%)$ bidentate intrastrand adducts with DNA. In adducts formed by both complexes, the rotation of the nitroxyl radicals is equally slow (Fig. 8) (correlation time $\tau \sim 10^{-8} \mathrm{~s}^{-1}$ ).

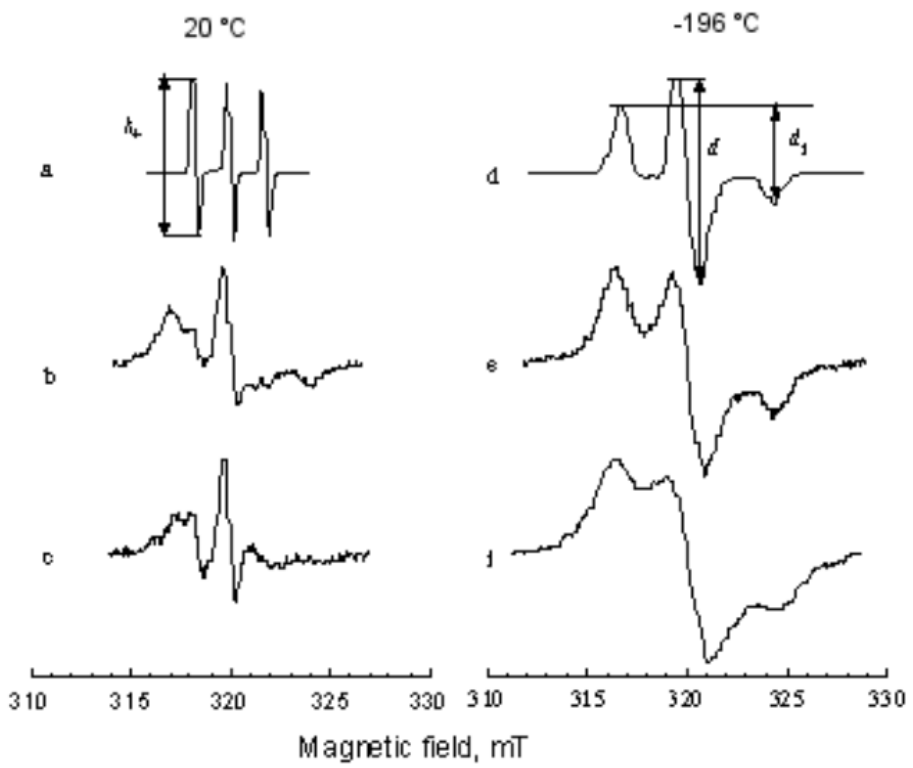

Figure 8. EPR spectra of free $4 \mathrm{~d}$ in water (a) and ethanol (d), and DNA modified by $4 \mathbf{d}(\mathrm{b}, \mathrm{e})$, and $30 \mathrm{~b}$ (c, f) in aqueous $0.01 \mathrm{M} \mathrm{NaHCO}_{3}$ at Pt-to-nucleotide ratio $r=0.16,37^{\circ} \mathrm{C}, 24 \mathrm{~h}$. Spectra were recorded at magnetic modulation $0.32 \mathrm{mT}$, microwave power $5\left(20^{\circ} \mathrm{C}\right)$ and $0.5 \mathrm{~mW}\left(-196^{\circ} \mathrm{C}\right)$, field scan $20 \mathrm{mT}$, scan time $8 \mathrm{~min}$, time constant $1 \mathrm{~s}$. 
This result can be explained by immobilization of the radical moiety in the major DNA groove for the complex $3 \mathrm{ob}$ adducts, and by the immobilization and/or by rigid structure of the double bound radical moiety in adducts formed by complex $4 \mathrm{~d}$. Adducts formed by complexes $\mathbf{3}_{1} \mathrm{~b}$ and $\mathbf{3}_{2} \mathrm{C}$ whose radical moiety is separated from the Pt atom by the methylene or ethylene bridge, are characterized by an order of magnitude lower values of the parameter $\tau$. Presumably, this phenomenon is related to partial release of nitroxyl moiety from relatively shallow major groove of DNA, which increases its rotational mobility (Sen', 2002).

Exciting opportunities for the instrumental use of PNCs were shown by Dunham et al., 1998. An adduct of 3oa complex with synthetic DNA fragment containing 11 base pairs was synthesized. Its structure in solution was determined by NMR based on the dependence between paramagnetic broadenings of protons of DNA bases and distances between bases and nitroxyl radical. Formation of the adduct was proved to result in the bending of DNA molecule that forms the angle $\sim 80^{\circ}$ with respect to the major groove, whereas the minor groove becomes strongly broaden.

The ability of complexes $\mathbf{1}-\mathbf{5}$ to bind to the isolated DNA in vitro was determined under standard conditions and characterized by a parameter $r$, which is equal to the number of linked labels per one nucleotide. In the series of complexes with the same amino ligand $4 \mathrm{c}-$ e, parameter $r$ grows with the increase in the rate of hydrolysis of $\mathrm{X}$-ligands. Platinating activity of compounds with different amino ligands depends on the total volume of these ligands and/or their linear sizes. Bulky biradical complex $\mathbf{1 c}$ and complexes $\mathbf{3} \mathbf{1} \mathbf{b}$ and $\mathbf{3} 2 \mathbf{c}$, whose sizes are enlarged due to a methylene or ethylene bridge, bind to DNA 5 to 10 times less efficiently than cisplatin or complexes $4 \mathbf{c}$, d (Fig. 9).

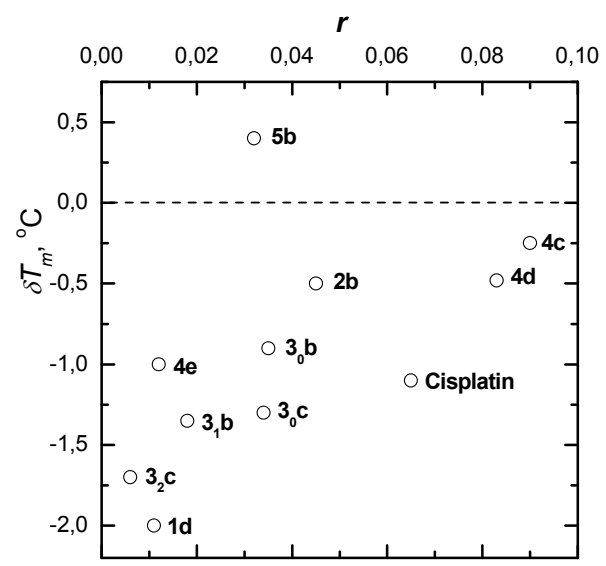

Figure 9. Relationship between the platinating activity $(r)$ and specific destabilization of the DNA duplex $\left(\delta T_{\mathrm{m}}\right)$ for PNCs. The platination of DNA was carried out in $0.01 \mathrm{M} \mathrm{NaHCO}_{3}$ over a period of $24 \mathrm{~h}$ at $37^{\circ} \mathrm{C}$ at the initial molar ratio $r_{\text {in }}=0.1$.

Ordinates in Fig. 9 are the values of specific destabilization of the DNA duplex, $\delta T_{m}$, that corresponds to the decrease in the DNA melting temperature due to formation of one adduct per 100 nucleotides. These values were calculated according to the formula 


$$
\delta T_{m}=\left(T_{m}{ }^{\prime}-T_{m}\right) / 100 r,
$$

where $T_{m}$ and $T_{m}{ }^{\prime}$ are the melting points for unmodified and platinated DNA, respectively. The data in Fig. 9 show that the low-activity complexes (with low $r$-values) cause the greatest disorder in the DNA duplex. Presumably, adducts of these complexes are readily recognized by the repair machinery. This is in agreement with the data on low antitumor activity of such complexes (see below). The binuclear complex $5 \mathbf{b}$ stabilizes DNA due to a predominant $(\sim 70 \%)$ formation of the interstrand crosslinks interfering with the thermal dissociation of the DNA duplex. It is interesting that bi- and trinuclear platinum amino complexes exhibit cytotoxic properties different from that of mononuclear ones, in particular, the former are active against cisplatin-resistant cells (Farrell et al., 1999).

\section{Cytotoxicity of PNCs in tumor cell cultures}

A simplified mechanism of cytotoxic effect of cisplatin and its analogs includes the transport of the complexes into the cell, their activation by the hydrolysis of leaving ligands $\left(\mathrm{Cl}^{-}\right.$, carboxylates), penetration into the nucleus, and formation of adducts with DNA (Kelland, 2007; Wheate et al., 2010). The DNA lesions are either repaired, or initiate a complex process of programmed cell death, i.e., apoptosis. In addition, it is known that cisplatin, directly or indirectly, causes the generation of reactive oxygen species. This process is important for the initiation of apoptosis (Miyajima et al., 1997; Bragado et al., 2007) and may also be responsible for side effects, e.g. nephrotoxicity (Tsutsumishita et al., 1998).

Nitroxyl radicals are antioxidants, which can react with active radicals not only stoichiometrically, but also act as catalysts of redox reactions and mimetics of enzymatic systems. For example, in aqueous medium they perform superoxide dismutation through the reduction of radical $\mathrm{HO}_{2}{ }^{\bullet}$ by nitroxyl radical and the oxidation of radical $\mathrm{O}_{2}{ }^{-}$by oxoammonium cation (Sen' et al., 1976, 2009; Goldstein et al., 2003) (Fig. 10).

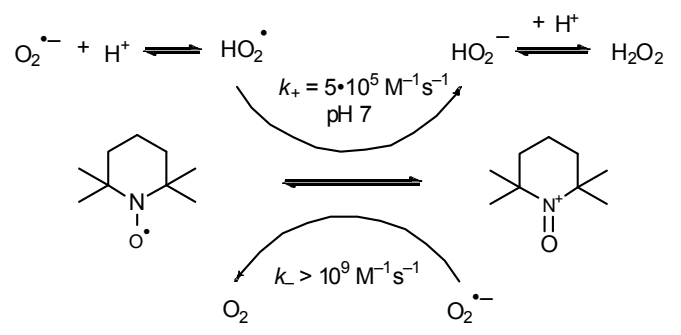

Figure 10. Superoxide dismutase-like activity of nitroxyl radicals

Interestingly, the nitroxyl based catalysis of dismutation of $\mathrm{HO}_{2}$ ' radical, generated in organic compounds undergoing oxidation, is carried out by the pair of nitroxyl radical/hydroxylamine (Denisov, 1996) (Fig. 11) Thermodynamic data are presented in support of the latter mechanism in organic medium. The measured constants of forward and reverse reactions at $50{ }^{\circ} \mathrm{C}$ are equal to $10^{4}-10^{5} \mathrm{M}^{-1} \cdot \mathrm{s}^{-1}$ (Denisov, 1996). Existence of two mechanisms for different media is not excluded. It looks reasonable that in an aqueous 


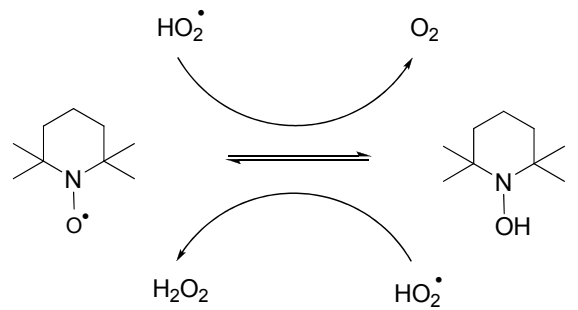

Figure 11. Catalytic disproportionation of radical $\mathrm{HO}_{2} \bullet$ in organic medium

medium the preferred process is an electron transfer followed by a thermodynamically favorable hydration of oxoammonium cation (Fig. 10), while in an organic medium more typical reactions are the redox processes involving a hydrogen atom transfer (Fig. 11). Therefore, in biphasic aqueous-organic systems present in biological objects, both mechanisms are possible.

Like other antioxidants, under certain conditions, nitroxyls may exhibit pro-oxidant activity. The structure and concentration of nitroxyls, the medium properties, and other hard-toidentify factors can determine their anti- or pro-oxidant effect. At submillimolar concentrations, nitroxyls, as a rule, exhibit antioxidant properties and protect cells from apoptosis (Wilcox, 2010). At millimolar concentrations, nitroxyls are cytotoxic toward cultured tumor cells (Gariboldi et al., 1998, 2000, 2003, 2006; Suy et al., 2005) and are active against model animal tumors (Konovalova et al., 1964; Suy et al., 2005). Nitroxyl radicals cause cell death both in the wild type and p53 mutant cells (Suy et al., 2005). The study of interplay of platinum and nitroxyl pharmacophores combined in one molecule is of interest also in connection with the recent discussions on application of antioxidants and redoxactive agents in tumor chemotherapy (Seifried, 2003; Wondrak, 2009).

To elucidate the interaction between platinum and nitroxyl pharmacophores, we studied the effect of 4-amino-2,2,6,6-tetramethylpiperidine-1-oxyl (4-amino-TEMPO) on the toxicity of cisplatin to HeLa cells. According to the published approach (Reynolds \& Maurer, 2005; Chou, 2006), the dose-response relationships were determined for individual agents and their mixtures at a fixed concentrations ratio. These data were transformed into the combination index (CI) - dead cells fraction (fa) dependence (Fig. 12). In a wide range of fraction affected $f a$, values of $\log (\mathrm{CI})$ are positive, which indicates antagonism of the agents. In the range of relatively high fraction affected, corresponding to millimolar concentrations of 4-amino-TEMPO, a transition to negative values of log (CI) takes place which means the mutual reinforcement of cytotoxicity, i.e., synergy. These results are consistent with the antioxidant properties of nitroxyls at low and their pro-oxidant properties at high concentrations.

Data on the cytotoxicity of PNCs also reflects the antagonism of platinum and nitroxyl pharmacophores. Complexes of platinum (II) $\mathbf{2} \mathbf{b}$ and $\mathbf{3} \mathbf{0} \mathbf{b}$, containing nitroxyl radicals of different structure, are significantly less toxic to tumor cells compared to cisplatin (Table 1). 


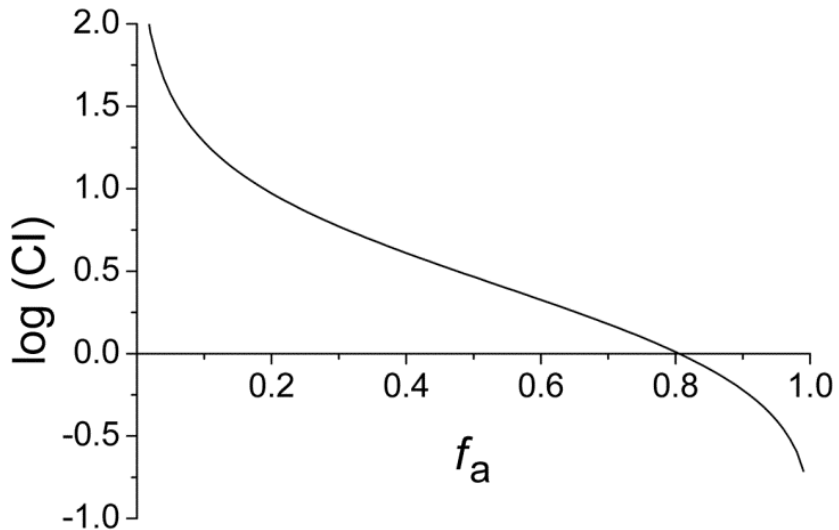

Figure 12. Combination index $[\log (\mathrm{CI})]$ versus fraction affected $\left(f_{\mathrm{a}}\right)$ of HeLa cells for combination of 4amino-2,2,6,6-tetramethylpiperidine-1-oxyl and cisplatin.

\begin{tabular}{|c|c|c|c|c|c|c|c|c|c|c|c|}
\hline \multirow{2}{*}{$\begin{array}{l}\text { Cell } \\
\text { line }\end{array}$} & \multicolumn{11}{|c|}{$\mathrm{IC}_{50,}, \mu \mathrm{M}$} \\
\hline & $\begin{array}{l}\text { Cis- } \\
\text { platin }\end{array}$ & $2 b$ & $30 b$ & JM216 & $9 b$ & $9 c$ & $10 \mathrm{~b}$ & $10 c$ & $10 \mathrm{~d}$ & $10 \mathrm{e}$ & $10 f$ \\
\hline HeLa & 14.8 & 125 & 112 & 14.4 & $>200^{*}$ & 13.4 & 200 & 4.18 & 2.45 & 0.23 & 0.09 \\
\hline H1299 & 66.7 & $>150^{*}$ & $>150^{*}$ & 38.8 & $>200^{*}$ & 25.4 & 220 & 24.6 & 16.6 & 1.36 & 0.69 \\
\hline
\end{tabular}

Table 1. 50\% Inhibitory concentrations for PNCs in HeLa and H1299 cells; MTT assay, 24 h of exposure. ${ }^{*}$ Evaluation of $\mathrm{IC}_{50}$ is limited by low solubility of complexes.

Platinum(IV)-nitroxyl complexes $\mathbf{9 b}$ and $\mathbf{1 0 b}$, being structurally close to JM-216, are also considerably less toxic to cells compared to the latter. Elongation of axial ligands $\mathrm{Y}$ increases both lipophilicity and cytotoxicity (complexes 9c and 10c-f), which is obviously due to the increased accumulation of complexes in cells (Fig. 13).

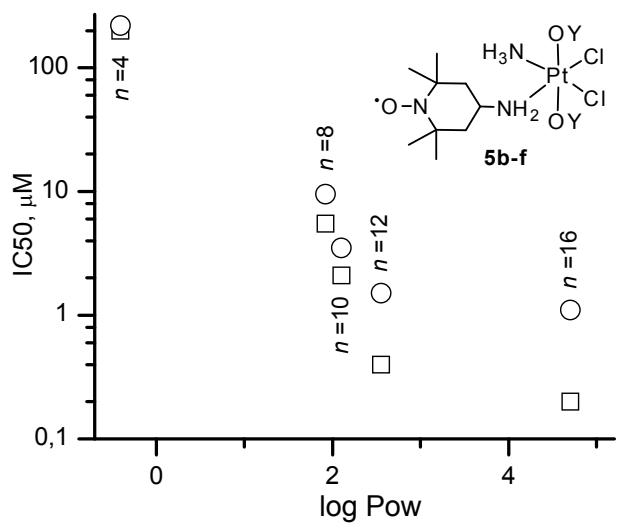

Figure 13. Relationship between lipophilicity (log Pow) and cytotoxicity (IC50) of complexes 10b-f in HeLa ( $\square$ ) and H1299 (O) cell lines; $\boldsymbol{n}$ means the total number of carbon atoms in carboxylic residues Y. 
The H1299 cells are less sensitive to platinum complexes. Unlike the HeLa cells, H1299 cells do not contain p53 protein because of mutations of p53 gene in both alleles (Mitsudomi et al., 1992). Since p53 protein plays a key role in the process of apoptosis in response to DNA damages (Vousden \& Prives, 2009), the observed lower sensitivity of H1299 cells to platinum complexes compared to HeLa cells can be related to lack of p53 function.

Our further study was focused on complex 10d since it combined high cytotoxicity with sufficient solubility in water. The effect of complex 10d and cisplatin on the cell cycle of HeLa and H1299 cells was studied (Fig. 14). According to flow cytofluorimetry data, both complexes cause approximately fivefold increase in the number of HeLa cells in the subG1 fraction, thus indicating induction of cell death. Accumulation of HeLa cells in early $S$ phase was also observed, which suggests that cell death is induced after cell cycle arrest during DNA synthesis. For H1299 cells, some increase in the S phase population and two-fold decrease in G2/M phases population was demonstrated, which shows cytostatic activity of the complexes without significant cell death.

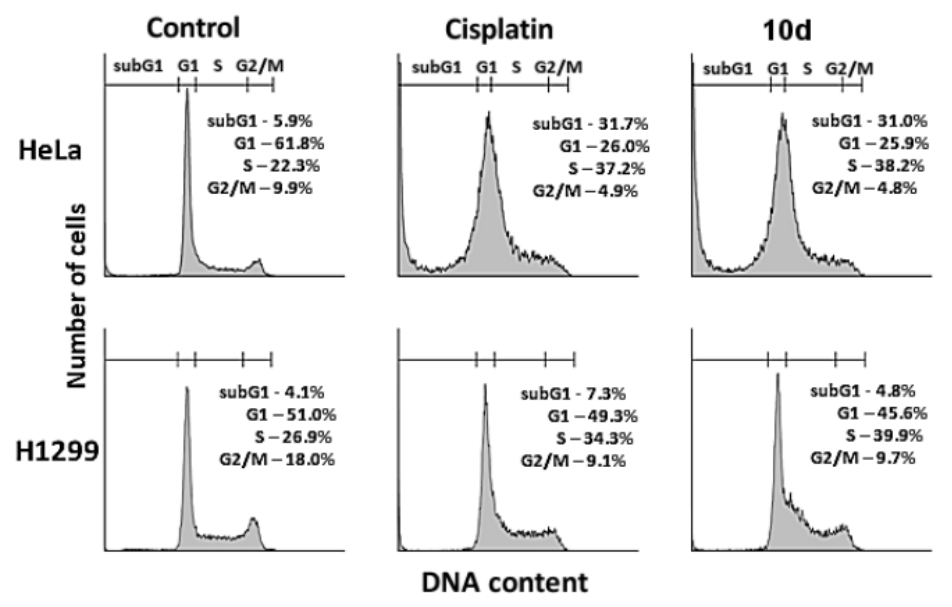

Figure 14. Cell cycle analysis of HeLa and H1299 cells treated with cisplatin and complex 10d (concentration IC $50,24 \mathrm{~h}$ ).

Cell death found in flow cytofluorimetry experiments was shown to be apoptotic. Both cisplatin and complex 10d cause in HeLa cells characteristic for apoptosis morphological changes of cell nuclei and internucleosomal cleavage of DNA leading to electrophoretic DNA laddering (Fig. 15a-d).

As it was discussed above, cisplatin and its analogues form adducts with DNA that, when are not repaired, trigger the tumor suppressor protein p53 (Alderden et al., 2006; Kelland, 2007; Wheate et al., 2010). Unlike cisplatin, the 10d complex does not cause increase of the p53 protein expression in MCF7 cells containing wild-type p53 gene (Fig. 15e). This finding indicates differences in the mechanism of cytotoxic action of these two complexes. Interestingly, on the rat glioma C6 cells, the simple nitroxyl Tempol was shown to cause apoptosis without elevation of p53 protein levels (Gariboldi et al., 2003). Many compounds 

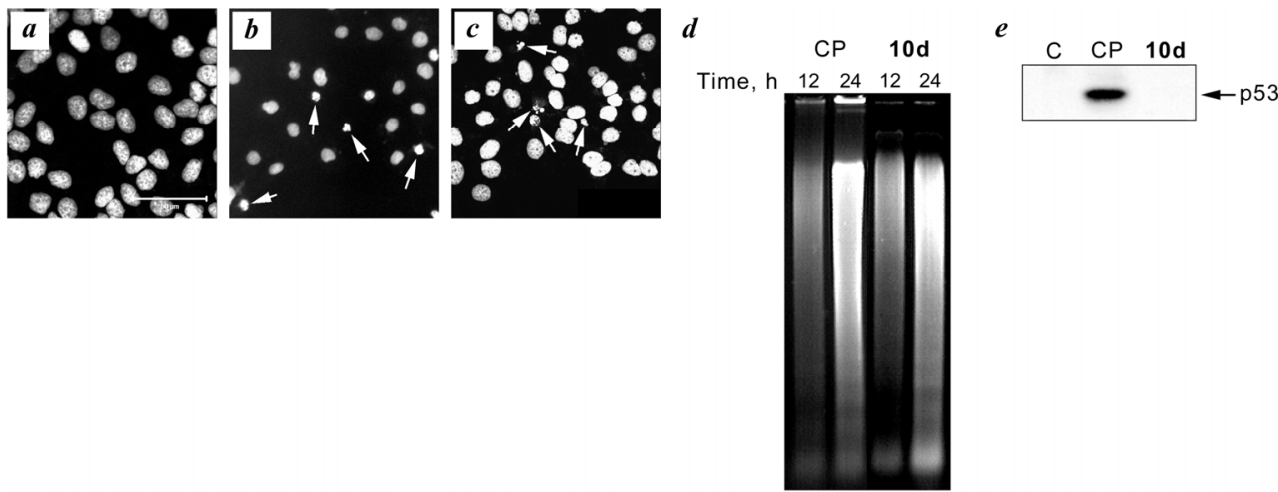

Figure 15. The mechanism of cytotoxicity of platinum complexes. $a-c$ DAPI staining of DNA in HeLa cells in the control (a) and after $24 \mathrm{~h}$ exposure to cisplatin (CP) (b) or complex 10d (c); arrows indicate the fragmented nuclei of the apoptotic cells. $d$ Agarose gel electrophoresis of HeLa cells DNA after $12 \mathrm{~h}$ and $24 \mathrm{~h}$ exposure to CP and complex 10d. $e$ Immunoblotting of MCF7 cell lysates with antibody to p53 in the control (C) and after $6 \mathrm{~h}$ exposure to $\mathrm{CP}$ and complex $\mathbf{1 0 d}$.

including nitroxyls (Sui at al., 2005) and platinum complexes (Gorczyca et al., 1993; Kalimutho et al., 2011; Roubalová et al., 2010) induce apoptosis both in cells with wild-type p53 gene and in p53-deficient cells. However, p53-independent apoptosis of tumor cells harboring wild-type p53 gene, to our knowledge, was observed for the first time.

\section{Antitumor activity of PNCs in animal experimental tumors}

Data on cytotoxicity revealed from cell culture studies and antitumor activity observed in animal tumor models do not correlate for platinum complexes. A striking example of this phenomenon is carboplatin, the known antitumor chemotherapy drug possessing negligible cytotoxicity in vitro. Carboplatin has been approved for clinical use because of favorable efficiency to toxicity ratio found in animal tumor models (Jakupec et al., 2008).

\section{1. $\mathrm{Pt}(\mathrm{II})$ complexes}

Toxicity and biological activity of Pt(II) diamino complexes depend on the structure of both the carrier amino ligands and the leaving groups, the latter being replaced during metabolism and target binding (Ho et al., 2003). The biradical complexes 1 containing two bulky amino ligands poorly bind to DNA in vitro (see above) and exhibit low toxicity and antitumor activity in vivo (Table 2).

Complexes 2 and 3 bearing one bulky substituent are close in their properties to cisplatin. Their $L D_{50}$ values are only 1.5 to 2.5 -fold higher than that of cisplatin. They efficiently platinate DNA and exhibit antitumour activity comparable with cisplatin. Influence of the nitroxyl structure on the complex activity can be seen when comparing complexes $\mathbf{2} \mathbf{b}$ and $\mathbf{3} \mathbf{b} \mathbf{b}$ that differ only in the size of nitroxyl cycle. Compound $3 \mathbf{b} b$ is both more toxic and more active against leukemia P388. For complexes 4, the correlation between the rate of leaving ligands 


\begin{tabular}{|c|c|c|c|}
\hline Complex & $L D_{50,} \mathrm{mg} \cdot \mathrm{kg}^{-1}\left(\mathrm{mM} \cdot \mathrm{kg}^{-1}\right)$ & Single dose, $\mathrm{mg} \cdot \mathrm{kg}^{-1}$ & $I L S, \%$ \\
\hline $\mathbf{1 b}$ & $570(0.94)$ & 190 & $106(0)$ \\
\hline $\mathbf{1 c} \cdot \mathrm{H}_{2} \mathrm{O}$ & $500(0.74)$ & 166 & $79(1)$ \\
\hline $\mathbf{1 d}$ & $380(0.61)$ & 127 & $76(0)$ \\
\hline $\mathbf{2 b}$ & $27(0.061)$ & 6.8 & $237(1)$ \\
\hline $\mathbf{3 0 b}$ & $15(0.033)$ & 3.8 & $292(2)$ \\
\hline $\mathbf{4 b}$ & $80(0.18)$ & 16 & $189(0)$ \\
\hline $\mathbf{4 c}$ & $11(0.022)$ & - & - \\
\hline $\mathbf{4 d} \cdot \mathbf{2} \mathrm{H}_{2} \mathrm{O}$ & $50(0.10)$ & 11 & $132(0)$ \\
\hline $\mathbf{4 e}$ & $500(0.95)$ & 133 & $202(2)$ \\
\hline $\mathbf{9 a}$ & $45(0.095)$ & 15 & $133(0)$ \\
\hline $\mathbf{9 b}$ & $100(0.180)$ & 34 & $247(0)$ \\
\hline $\mathbf{1 0 a} \cdot 2 \mathrm{H} \mathrm{H}_{2} \mathrm{O}$ & $27(0.052)$ & 9 & $270(4)$ \\
\hline $\mathbf{1 0 b}$ & $46(0.080)$ & 7.5 & $220(4)$ \\
\hline $\mathbf{1 0 d}$ & $4.5(0.007)$ & 1.5 & $120(1)$ \\
\hline $\mathbf{1 1 b}$ & $260(0.38)$ & 87 & $290(1)$ \\
\hline Cisplatin & $12(0.040)$ & 3.0 & $245(1)$ \\
\hline
\end{tabular}

Table 2. Toxicity $\left(L D_{50}\right)$ and antileukemic (P388) activity (ILS) of PNCs. $L D 50$ is a dose which is lethal to $50 \%$ of healthy mice. Increase in the life span $I L S=[100(T / C-1)]$, where $T$ and $C$ the average life-time (days) of treated and control animals, respectively. The numbers of animals survived for more than 60 days in the group of six animals are given in brackets.

hydrolysis and the toxicity was established (Sen' et al., 1996; Shugalii et al., 1998). Readily hydrolyzable $4 \mathrm{c}$ has the highest toxicity whereas $4 \mathbf{e}$, the most slowly hydrolyzable compound among complexes 4, exhibits the lowest toxicity, but, like carboplatin, it possesses good antitumor activity only at high doses. Compound $\mathbf{4 d}$, the structural analogue of oxaliplatin, is approximately 2-fold less toxic compared to the latter. The observed decrease in toxicity might be due to the influence of the nitroxyl group. The data presented demonstrate that, among $\mathrm{Pt}(\mathrm{II})$ complexes with amino nitroxyl radicals, high antitumor activity in vivo is characteristic for those that contain no more than one bulky amino ligand, platinate DNA with high efficiency, and cause moderate destabilization of DNA duplex (Fig. 9, Table 2).

\subsection{Pt(IV) complexes}

Toxicity of Pt(IV) complexes $\mathbf{9}$ and $\mathbf{1 0}$ varies in the wide range depending on the structure of axial ligands. Compounds $\mathbf{9 a}, \mathbf{b}$ and $\mathbf{1 0 a}, \mathbf{b}$ are 1.6 to 3 -fold less toxic compared to the corresponding Pt (II) analogues, 2 and 3 (Table 2). As in the case of divalent complexes, the piperidine oxyl derivatives $\mathbf{1 0}$ are both more toxic and more active against leukemia P388 than pyrrolidine oxyl derivatives 9. 
An important feature of PNCs is found in comparative study of development of tumor resistance in leukemia P388 to complex 10a and cisplatin (Sen' et al., 2003; Goncharova et al., 2011). The development of resistance was induced by sequential inoculation of tumor cells from animals treated with equitoxic doses of drugs. The tumor acquired resistance $(\leq 20 \%$ of the sensitivity of the parent tumor) to cisplatin at the 4th and to complex 10a at the 10th generation of tumor (Fig. 16). This data demonstrate that the resistance to complex 10a develops 2.5-fold slower than that to cisplatin.

Interesting results were observed when PNCs and cisplatin were used in combination at low doses (1/10 to $1 / 20$ of $L D_{50}$ ) for leukemia P388 treatment. Individual compounds in the same doses caused low ILS-indices with no cured animals, but their combinations cured up to $100 \%$ of mice (Fig. 17).

Complexes 10a and $10 \mathrm{~b}$ containing piperidinoxyl moiety exhibit higher antitumor activity compared to that of complex $\mathbf{9 b}$, both as single agents and in combination with cisplatin. Thus, small difference in the structure of nitroxyl radicals in these PNCs has a significant influence on their antitumor activity in vivo.

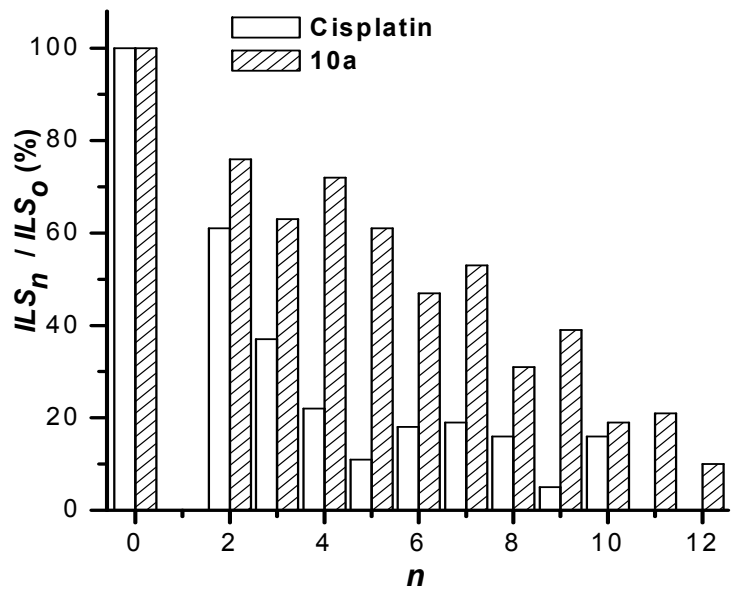

Figure 16. Development of resistance to cisplatin and complex 10a in a series of successive transplant generations $(n) . I L S_{0}$ is the increase in the life span of treated animals bearing the sensitive (parent) generation of leukemia P388.

It is known that reduction potentials $E_{1 / 2}\left(>\mathrm{N}^{+}=\mathrm{O} />\mathrm{N}-\mathrm{O}^{\bullet}\right)$ of nitroxyls of piperidine series are, on the average, approximately $0.1 \mathrm{~V}$ lower than that of radicals of pyrrolidine series (Goldstein et al., 2006; Manda et al., 2007; Sen' \& Golubev, 2009). Therefore, piperidinoxyls are oxidized by $\mathrm{HO}_{2}{ }^{-}$radical more readily (Fig. 10), and they are more efficient superoxide dismutase mimetics compared to pyrrolidinoxyls (Goldstein et al., 2006). At the same time, in vivo, pyrrolidinoxyls undergo reduction to corresponding hydroxylamines about tenfold slower than piperidinoxyls (Komarov et al., 1994). Along with possible differences in pharmacokinetics of the complexes, these features of the redox properties of nitroxyls, presumably, affect the biological activity of PNCs. 


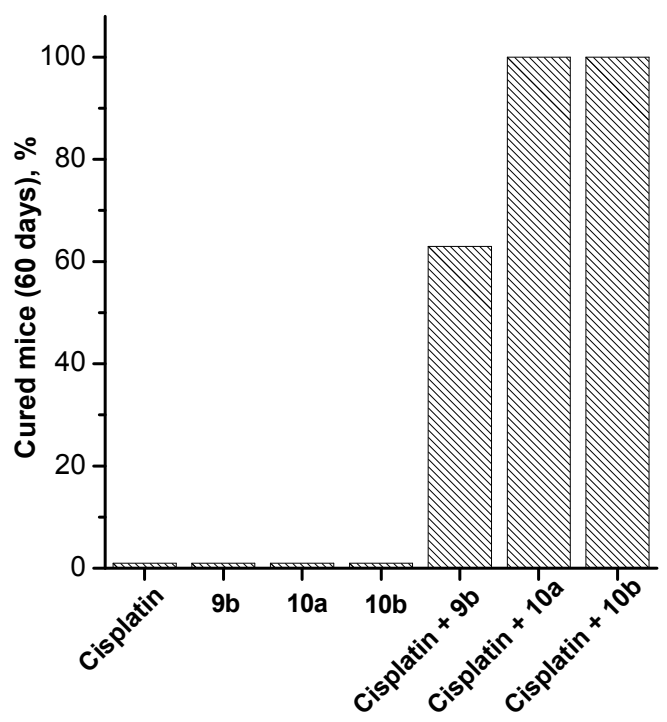

Figure 17. Synergy for the antitumor effect of cisplatin $(0.6 \mathrm{mg} / \mathrm{kg})$ combined with complexes $9 \mathbf{b}(2,3$ $\mathrm{mg} / \mathrm{kg}), 10 \mathrm{a}(1,4 \mathrm{mg} / \mathrm{kg}$ ) or $10 \mathrm{~b}(5,0 \mathrm{mg} / \mathrm{kg}$ ) against leukemia P388 (days of treatment $1,3,5,7)$.

\section{Conclusion}

Recent studies (Wondrak, 2009; DeNicola et al., 2011) show that modulation of the redox state of cancerous cells could provide a new approach to suppression of tumor growth. Effects of nitroxyl radicals on the redox processes in normal cells and their cytotoxicity in tumor cells are documented in many examples (Gariboldi et al., 2000; Suy et al., 2005; Wilcox, 2010). Presumably, nitroxyls may affect the tumor cell viability through a redoxmediated signaling, which ultimately activate apoptosis.

On the other hand, the influence of nitroxyl radical on activity of anticancer agent, when they are used in combination or are covalently linked in one molecule, appears to depend on local concentration of radicals. At low concentrations of nitroxyls, which corresponds to rather low therapeutic doses of hybrid compounds, radicals are likely to impair the oxidative stress caused by tumor process and an anticancer agent itself. Published data show that in vivo the overall and/or specific toxicity may be reduced for hybrid compounds without significant loss of antitumor activity. On the other hand, high concentrations of nitroxyls, which can be implemented in combinations with anticancer agents, increase the intrinsic oxidative stress in tumor cells and exert a selective cytotoxic effect.

The known active anticancer complexes like cisplatin, oxaliplatin, and satraplatin bear in their structure redox-inert amino ligands. We synthesized structurally close analogs, i.e., platinum-nitroxyl complexes, amino ligands of which hold a wide spectrum of redox activity and are able to modulate biological properties of the new compounds. Their 
physicochemical properties, interaction with DNA, cytotoxicity in vitro and antitumor activity in vivo were studied. A limited correlation was found between the ability of new complexes to form adducts with DNA, thermal stability of these adducts and antitumor activity of the complexes. PNCs are characterized by features that distinguish them from platinum complexes with usual alkylamines. An antagonism of platinum and nitroxyl pharmacophore was observed in cell culture. As compared to cisplatin or satraplatin, structurally close nitroxyl derivatives are approximately 10 times less cytotoxic. This may be explained by a moderate inhibition of p53-dependent apoptosis due to the antioxidant properties of nitroxyl radicals. These in vitro findings do not correlate with in vivo data, and antitumor activities of some PNCs and cisplatin are approximately the same. The relatively slow development of resistance to PNCs and the presence of synergy for the combinations of PNCs and cisplatin imply the differences in the mechanism of antitumor action of cisplatin and PNCs. Due to antioxidant properties (Sen' et al., 2000), nitroxyls in PNCs may ameliorate side effects typical for cisplatin, such as nephrotoxicity and neurotoxicity. For example, nitroxyl derivative of daunorubicin, ruboxyl, has virtually no cardiotoxicity that limits therapeutical doses of the parental compound (Emanuel \& Konovalova, 1992). Reduced side effects, in turn, contribute to the better survival and, as a result, the higher efficacy of tumor chemotherapy in vivo. Our and literature data show that nitroxyls are promising modulators of the activity of anticancer agents and, as such, could be approved for clinical use.

\section{Author details}

Vasily D. Sen', Alexei A. Terentiev and Nina P. Konovalova

Institute of Problems of Chemical Physics, Russian Academy of Sciences, Chernogolovka, Russian Federation

\section{Acknowledgement}

This work was partly supported by the Russian Foundation for Basic Research (Project No. 09-03-01187).

\section{References}

Alderden, R.A., Hall, M.D., \& Hambley, T.W. (2006). The Discovery and Development of Cisplatin. J. Chem. Education., Vol.83, No.5, pp. 728-734.

Blokhin, N.N., \& Perevodchikova, N.I. (1984). Khimioterapiya opukholevykh zabolevanii (Chemotherapy of Neoplastic Diseases), Meditsina, Moscow, (in Russian).

Bonetti, A., Leone, R., Muggia, F.M., \& Howell, B. (Eds.). (2009). Platinum and other Heavy Metal Compounds in CancerChemotherapy, Humana Press, ISBN 978-1-60327-458-6, New York. 
Bravado, P., Armesilla, A., Silva, A., \& Porras, A. (2007). Apoptosis by Cisplatin Requires p53 Mediated p38a MAPK Activation through ROS Generation. Apoptosis, Vol.12, No.9, pp. 1733-1742.

Chekhlov, A.N. (2005). Crystal and Molecular Structures of (trans-3,4-Diamino-2,2,6,6tetramethylpiperidine-1-oxyl- $\left.\mathrm{N}^{3}, \mathrm{~N}^{4}\right)($ oxalato-O,O')platinum(II). Russ. J. Coord. Chem. Vol.31, No.3, pp. 179-182.

Chou, T.C. (2006). Theoretical Basis, Experimental Design, and Computerized Simulation of Synergism and Antagonism in Drug Combination Studies. Pharmacol. Rev., Vol.58, No.3, pp. 621-681.

Claycamp, H.G., Shaw, E.I., \& Zimbrick, J.D. (1986) Spin-Label Substitutions in Cisplatin Reduce Toxicity and Interaction with Radiation. Radiation Res., Vol.106, No.2, pp. 141146.

DeNicola, G.M., Karreth, F.A., Humpton, T.J., Gopinathan, A., Wei C., Frese, K., Manga, D., Yu K.H, Yeo, C.J., Calhoun, E.S., Scrimieri, F., Winter, J.M., Hruban, R.H., IacobuzioDonahue, C., Kern, S.E., Blair, I.A., \& Tuveson, D.A. (2011). Oncogene-Induced Nrf2 Transcription Promotes ROS Detoxification and Tumorigenesis. Nature, Vol.475, 7 July, pp. 106-109.

Denisov, E.T. (1996) Cyclic Mechanisms of Chain Termination in the Oxidation of Organic Compounds. Russ. Chem. Rev. Vol.65, No.6, pp. 505-520.

Dhara, S.C. (1970). A Rapid Method for the Synthesis of cis-[ $\left.\mathrm{Pt}\left(\mathrm{NH}_{3}\right)_{2} \mathrm{Cl}_{2}\right]$. Indian J. Chem., Vol.8, No.1, p. 193.

Dunham, Sh.U., Dunham, S.U., Turner, C.J., \& Lippard, S.J. (1998). Solution Structure of a DNA Duplex Containing a Nitroxide Spin-Labeled Platinum d(GpG) Intrastrand CrossLink Refined with NMR-Derived Long-Range Electron-Proton Distance Restraints. J. Am. Chem. Soc., Vol.120, No.22, pp. 5395-5406.

Emanuel, N.M., Konovalova, N.P., \& Djachkovskaya, R.F. (1976). Toxicity, Antitumor Activity, and Pharmacokinetics of Spin-labeled ThioTEPA Analogs. Cancer Treat. Rep. Vol. 60, No.11, pp. 1605-1609.

Emanuel, N.M., Konovalova, N.P., Povarov, L.S., Shapiro, A.B., Dyachkovskaya, R.F., Suskina, V.I., \& Denisova, L.K. (1982). 13-(1-Oxyl-2,2,6,6-tetramethylpiperidin-4diyl)hydrazone Rubomicyn Hydrochloride with a Paramagnetic Center and a Method of Producing Same. US Pat. 4332934,

http://worldwide.espacenet.com/publicationDetails/biblio?DB=EPODOC\&II=3\&ND=3\& adjacent $=$ true\&locale $=$ en_EP\&FT $=D \&$ date $=19820601 \& C C=U S \& N R=4332934 A \& K C=A$.

Emanuel, N.M., Rosenberg, A.N., Golubev, V.A., Bogdanov, G.N., Vasil'eva, L.V., \& Konovalova, N.P. (1985). 5-Fluorouracyl Nitroxyl Derivatives Possessing Antitumor Activity. US Pat. 4558127,

http://worldwide.espacenet.com/publicationDetails/biblio?DB=EPODOC\&II=1\&ND=3\& adjacent $=$ true\&locale $=$ en_EP\&FT $=$ D\&date $=19851210 \& C C=U S \& N R=4558127$ A \&KC $=\mathrm{A}$.

Emanuel, N.M., Sen', V.D., Golubev, V.A., Bogdanov, G.N., Vasil'eva, L.V., \& Konovalova, N.P. (1986). Nitroxyl Derivatives of Nitrosourea Exhibiting Antitumor and Mutagenic Activity. SSSR Pat. 1259650, 
http://worldwide.espacenet.com/publicationDetails/biblio?DB=EPODOC\&II=8\&ND=3\& adjacent $=$ true\&locale $=$ en_EP\&FT $=$ D\&date $=19900623 \& C C=S U \& N R=1259650 A 1 \& K C=A 1$. Emanuel, N.M., \& Konovalova, N.P. (1992). Nitroxyl Radicals for Cancer Chemotherapy, In: Bioactive Spin Labels, Zhdanov, R.I. (Ed.). pp. 439-460, Springer, ISBN 3-54-53811-9, Berlin.

Farrell, N., Qu, Y., Bierbach, U., Valsecchi, M., \& Menta, E. (1999). Structure-Activity Relationships Within Di- and Trinuclear Platinum Phase-I Clinical Anticancer Agents, In: Cisplatin: Chemistry and Biochemistry of a Leading AnticancerDrugs, B. Lippert, (Ed.), pp. 479-496, Verlag Helvetica Chimica Acta, ISBN 3-906390-20-9, Zurich.

Frey, U., Ranford, J.D., \& Sadler, P.J. (1993). Ring-opening Reactions of the Anticancer Drug Carboplatin: NMR Characterization of cis-[Pt( $\left.\mathrm{NH}_{3}\right)_{2}\left(\mathrm{CBDCA}^{-\mathrm{O})}\left(5^{\prime}-\mathrm{GMP}^{\left.-N^{7}\right)}\right)\right.$ in Solution. Inorg. Chem., Vol.32, No.8, pp. 1333-1340.

Gariboldi, M.B., Lucchi, S., Caserini, C., Supino, R., Oliva, C., \& Monti, E. (1998). Antiproliferative Effect of the Piperidine Nitroxide Tempol on Neoplastic and Nonneoplastic Mammalian Cell Lines. Free Rad. Biol. Med., Vol.24, No.6, pp. 913-923.

Gariboldi, M.B., Rimoldi, V., Supino, R., Favini, E., \& Monti, E. (2000). The Nitroxide Tempol Induces Oxidative Stress, p21WAF1/CIP1, and Cell Death in HL60 Cells. Free Rad. Biol. Med., Vol.29, No.7, pp. 633-641.

Gariboldi, M.B., Ravizza, R., Petterino, C., Castagnaro, M., Finocchiaro, G., \& Monti, E. (2003). Study of in vitro and in vivo Effects of the Piperidine Nitroxide Tempol-a Potential New Therapeutic Agent for Gliomas. Eur. J. Cancer, Vol.39, No.6, pp. 829-837.

Gariboldi, M.B., Terni, F., Ravizza, R., Meschini, S., Marra, M., Condello, M., Arancia, G., \& Monti, E. (2006). The Nitroxide Tempol Modulates Anthracycline Resistance in Breast Cancer Cells. Free Rad. Biol. Med., Vol.40, No.8, pp. 1409-1418.

Giandomenico, C.M., Abrams, M.J., Murrer, B.A., Vollano, J.F., Rheinheimer, M.I., Wyer, S.B., Bossard, G.E., Higgins, J. D. (1995). Carboxylation of Kinetically Inert Platinum(IV) Hydroxy Complexes. An Entrée into Orally Active Platinum(IV) Antitumor Agents. Inorg. Chem., Vol.34, No.5, pp. 1015-1021.

Goldstein, S., Merenyi, G., Russo, A., \& Samuni, A. (2003). The Role of Oxoammonium Cation in the SOD-Mimic Activity of Cyclic Nitroxides. J. Am. Chem. Soc. Vol.125, No.3, pp. 789-795.

Goldstein, S., Samuni, A., Hideg, K., \& Merenyi, G. (2006). Structure-Activity Relationship of Cyclic Nitroxides as SOD Mimics and Scavengers of Nitrogen Dioxide and Carbonate Radicals. J. Phys. Chem. A. Vol.110, No.10, pp. 3679-3685.

Gorczyca, W., Gong, J., Ardelt, B., Traganos, F., \& Darzynkiewicz, Z. (1993). The Cell Cycle Related Differences in Susceptibility of HL-60 Cells to Apoptosis Induced by Various Antitumor Agents. Cancer Res., Vol.53, No.13, pp. 3186-3192.

Hambley T.W. (1997). The Influence of Structure on the Activity and Toxicity of Pt Anticancer Drugs. Coord. Chem. Rev., Vol.166, November 1997, pp. 181-223.

Ho, Y.P., Au-Yeung, S.C., To, K.K. (2003). Platinum-based Anticancer Agents: Innovative Design Strategies and Biological Perspectives. Med. Res. Rev., Vol.23, No.5, pp. 633-655.

Huang, J.C., Zamble, D.B., Reardon, J.T., Lippard, S.J., \& Sancar, A. (1994). HMG-Domain Proteins Specifically Inhibit the Repair of the Major DNA Adduct of the Anticancer 
Drug Cisplatin by Human Excision Nuclease. Proc. Natl. Acad. Sci. USA. Vol.91, No.22, pp. 10394-10398.

Jakupec, M.A., Galanski, M., Arion, V.B., Hartinger C.G., \& Keppler, B.K. (2008). Antitumour Metal Compounds: More than Theme and Variations. Dalton Trans., No.2, pp. 183-194.

Kalimutho, M., Minutolo, A., Grelli, S,. Federici, G., \& Bernardini, S. (2011). Platinum-(IV)Derivative Satraplatin Induced G2/M Cell Cycle Perturbation via p53-p21(waf1/cip1)independent Pathway in Human Colorectal Cancer Cells. Acta Pharmacol. Sin., Vol. 32, No.11, pp. 1387-1396.

Kelland, L. R. (1999). Cisplatin-based Anticancer Agents, In: Uses of Inorganic Chemistry in Medicine, Farrell, N.P. (Ed.). pp. 109-121, Springer, ISBN 0-85404-444-2, Berlin.

Kelland, L.R., (2007). The Resurgence of Platinum-Based Cancer Chemotherapy. Nature Rev., Vol.7, No.8, pp. 573-584.

Klein, A.V., \& Hambley, T.W. (2009). Platinum Drug Distribution in Cancer Cells and Tumors, Chem. Rev., Vol.109, No.10, pp. 4911-4920.

Klimek, M., (1966). Toxicity of N-Ethylmaleimide and Di-t-Butyl Nitroxide Radiosensitizers towards HeLa S3 Cells in a Single Cell Cultures. Nature. Vol.209, No.5029, pp. 12561257.

Koeberle, B., Tomicic, M.T., Usanova, S., \& Kaina, B. (2010). Cisplatin Resistance: Preclinical Findings and Clinical Implications, Biochim. Biophys. Acta, Vol.1806, No.2, pp. 172-182.

Komarov, A.M., Joseph, J., \& Lai, C.S. (1994). In Vivo Pharmacokinetics of Nitroxides in Mice. Biochem. Biophys. Res. Comm. Vol.201, No.2, pp. 1035-1042.

Konovalova, N.P., Bogdanov, G.N., Miller, V.B., Rozantsev, E.G., Neiman, M.B., \& Emanuel, N.M. (1964). Antitumor Activity of Stabile Free Radicals. Dokl. Akad. Nauk SSSR, Vol.157, No.3, pp. 707-709 [Dokl. Chem. (Engl. Transl.), 1964].

Konovalova, N.P., Diatchkovskaya, R.F., Volkova, L.M., \& Varfolomeev, V.N. (1991). Nitroxyl radicals decrease toxicity of cytostatic agents. Anticancer Drugs. Vol.2, No.6, pp. 591-595.

Manda, S., Nakanishi, I., Ohkubo, K., Yakumaru, H., Matsumoto, K., Ozawa, T., Ikota, N., Fukuzumi, S., \& Anzai, K. (2007). Nitroxyl Radicals: Electrochemical Redox Behaviour and Structure-Activity Relationships. Org. Biomol. Chem., Vol.5, No.24, pp. 3951-3955.

Mathew, A., Bergquist, B., \& Zimbrick, J. (1979). Synthesis of Spin-labelled Platinum Drugs and Interaction with Deoxyguanidine. Chem. Comm., No.2, pp. 222-224.

Mitsudomi, T., Steinberg, S.M., Nau, M.M., Carbone, D., D'Amico, D., Bodner, S., Oie, H.K., Linnoila, R.I., Mulshine, J.L., Minna, J.D., et al. (1992). p53 Gene Mutations in Nonsmall-cell Lung Cancer Cell Lines and their Correlation with the Presence of ras Mutations and Clinical Features. Oncogene, Vol.7, No.1, pp. 171-180.

Miyajima, A., Nakashima, J., Yoshioka, K., Tashibana, M., Tazaki, H., \& Murai, M. (1997). Role of Reactive Oxygen Species in cis-Dichlorodiammineplatinum-induced Cytotoxicity on Bladder Cancer Cells. British J. Cancer, Vol.76, No.2, pp. 206-210.

Monti, E., Cova, D., Guido, E., Morelli, R., \& Oliva, C. (1996). Protective Effect of the Nitroxide Tempol against the Cardiotoxicity of Adriamycin. Free Rad. Biol. Med. Vol.21, No.4, pp. 463-470. 
Oksanen, M., \& Leskela, M. (1994). Synthesis of Ammonium Trichloromonoammineplatinate(II) Improved through Control of Temperature. Acta Chim. Scand., Vol.48, No.2, pp. 485-489.

Oksanen, M. (1997). A Novel Characterization of the Structure of "Cossa's Salt" $K_{x}\left(\mathrm{NH}_{4}\right)_{1-}$ $x\left[\mathrm{PtCl}_{3}\left(\mathrm{NH}_{3}\right)\right] \cdot \mathrm{H}_{2} \mathrm{O}$ by Crystallographic Comparison with the Stoichiometric Compounds $\mathrm{K}\left[\mathrm{PtCl}_{3}\left(\mathrm{NH}_{3}\right)\right] \cdot \mathrm{H}_{2} \mathrm{O}$ and $\mathrm{NH}_{4}\left[\mathrm{PtCl}_{3}\left(\mathrm{NH}_{3}\right)\right] \cdot \mathrm{H}_{2} \mathrm{O}$. Inorg. Chim. Acta., Vol.269, No.1, pp. 53-60.

Potucka, L., Houskova, J., Syslova, K., Hamtil, R., Kacer, P., \& Cerveny, L. (2011). HPLC Method for the Determination of the Purity of $\mathrm{K}\left[\mathrm{Pt}\left(\mathrm{NH}_{3}\right) \mathrm{Cl}_{3}\right]$, a Precursor of the Platinum Complexes with Cytostatic Activity. Anal. Lett. , Vol.44, No.10-12, pp. 21822193.

Raikov, Z., Todorov, D., Ilarionova, M., Demirov, G., Tsanova, T., \& Kafalieva, D. (1985). Synthesis and Study of Spin-Labeled Nitrosoureas. Cancer Biochem. Biophys., Vol.7, No.2, pp. 343-348.

Reynolds, C.P. \& Maurer, B.J. (2005). Evaluating Response to Antineoplastic Drug Combinations in Tissue Culture Models. Methods Mol. Med.,Vol.110, pp. 173-183.

Roubalová, E., Kvardová, V., Hrstka, R., Borilová, S., Michalová, E., Dubská, L., Müller, P., Sova, P., \& Vojtesek, B. (2010). The Effect of Cellular Environment and p53 Status on the Mode of Action of the Platinum Derivative LA-12. Invest. New Drugs, Vol.28, No.4, pp. 445-453.

Satoh, M., Kashihara, N., Fujimoto, S., Horike, H., Tokura, T., Namikoshi, T., Sasaki, T., \& Makino, H. (2003). A Novel Free Radical Scavenger, Edarabone, Protects Against Cisplatin-induced Acute Renal Damage in vitro and in vivo. J. Pharmacol. Exp. Ther., Vol.305, No.3, pp. 1183-1190.

Sen', V.D., Golubev, V.A., Kulyk, I.V., \& Rozantsev, E.G. (1976). Mechanism of Reaction of Hydrogen Peroxide with Oxopiperidine Salts and Piperidinoxyl Radicals. Russ. Chem. Bull., Vol.25, No.8, pp. 1647-1654.

Sen', V.D., Golubev, V.A., \& Bogdanov, G.N. (1989a). Nitroxylcarbamoyl Derivatives of 5Fluorouracyl, Russ. Chem. Bull., Vol.38, No.10, pp. 2132-2135.

Sen', V.D., (1989b). Synthesis of 3,4-Diamino-2,2,6,6-tetramethylpiperidine-1-oxyl, Russ. Chem. Bull., Vol.38, No.9, pp. 1928-1931.

Sen', V.D., (1993). Synthesis of Nitroxide Derivatives of Alkylnitrosourea, Russ. Chem. Bull., Vol.42, No.3, pp. 548-551.

Sen', V.D., Golubev, V.A., Volkova, L.M., \& Konovalova, N. P. (1996). Synthesis and Antitumor Activity of Platinum(II) Complexes with trans-3,4-Diamino-2,2,6,6tetramethylpiperidine-1-oxyl. J. Inorg. Biochem., Vol.64, No.1, pp. 69-77.

Sen', V.D., Kulikov, A.V., Shugalii, A.V., \& Konovalova, N.P. (1998). Synthesis of Dinitroxyl cis-Diaminoplatinum(II) Complexes and their Interaction with DNA. Russ. Chem. Bull., Vol.47, No.8, pp. 1598-1602.

Sen', V.D., Rukina, N.A., Tkachev, V.V., Pis'menskii, A.V., Volkova, L.M., Goncharova, S.A., Raevskaya, T.A., Tikhomirov, A.G., Gorbacheva, L.B., \& Konovalova, N.P. (2000). Synthesis, Structure, and Biological Activity of Mixed-ligand Platinum(II) Complexes with Aminonitroxides. Russ. Chem. Bull., Vol.49, No.9, pp. 1613-1619. 
Sen', V.D., Shugalii, A.V., \& Kulikov, A.V. (2002). DNA Modification by cisDiaminoplatinum(II) Complexes with Aminonitroxide Ligands. Russ. Chem. Bull., Vol.51, No.6, pp. 11058-1064.

Sen', V.D., Tkachev, V.V., Volkova, L.M., Goncharova, S.A., Raevskaya, T.A., \& Konovalova, N.P. (2003). Synthesis, Structure, and Antitumor Properties of Platinum(IV) Complexes with Aminonitroxyl Radicals. Russ. Chem. Bull., Vol.52, No.2, pp. 421-426.

Sen', V.D., Golubev, V.A., Lugovskaya, N.Yu., Sashenkova, T.E., \& Konovalova N.P. (2006). Synthesis and Antitumor Properties of New Platinum(IV) Complexes with Aminonitroxyl Radicals. Russ. Chem. Bull., Vol.55, No.1, pp. 62-65.

Sen', V.D., \& Golubev, V.A., (2009). Kinetics and Mechanism for Acid-catalyzed Disproportionation of 2,2,6,6-Tetramethylpiperidine-1-oxyl. J. Phys. Org. Chem., Vol.22, No.2, pp. 138-143.

Shapiro, A.B., Kropacheva, A.A., Suskina, V.I., Rozynov, B.V., \& Rozantsev, E.G. (1971). Mass-spectrometric Study of Paramagnetic Derivatives of Ethylenephosphoramides. Russ. Chem. Bull., Vol.20, No.4, pp. 780-783.

Shugalii, A.V., Kulikov, A.V., Lichina, M.V., Golubev, V.A., \& Sen', V.D. (1998). Binding of Platinum-Diaminonitroxyl Complexes to Animal DNA. J. Inorg. Biochem., Vol.69, No.12, pp. 67-77.

Seifried, H.E., McDonald, S.S., Anderson, D.E., Greenwald, P., \& Milner, J. A. (2003). The Antioxidant Conundrum in Cancer. Cancer Res., Vol.63, August 1, pp. 4295-4298.

Sinha, B.K., Cox, M.G., Colin F. Chignell, C.F., \& Cysyk, R.L. (1979). Synthesis and Biological Properties of N2-Substituted Spin-Labeled Analogs of Actinomycin D. J. Med. Chem., Vol.22, No.9, pp. 1051-1055.

Siomek, A., Tujakowski, J., Gackowski, D., Rozalski, R., Foksinski, M., Dziaman, T., Roszkowski, K., \& Olinski, R. (2006). Severe Oxidatively Damaged DNA after Cisplatin Treatment of Cancer Patients. Int. J. Cancer, Vol.119, No.9, pp. 2228-2230.

Sosnovsky, G., Paul, B.D. (1984). In the Search for New Anticancer Drugs. 9. Synthesis and Anticancer Activity of Spin-Labeled Analogues of $\mathrm{N}, \mathrm{N}^{\prime} \mathrm{N}^{\prime}, \mathrm{N}^{\prime}: \mathrm{N}^{\prime \prime}, \mathrm{N}^{\prime \prime}-$ Tri-1,2Ethanediylphosphoric Triamide and N,N:N',N':N",N"-Tri-1,2Ethanediylphosphorothioic Triamide. J. Med. Chem.Vol.27, No.6, pp. 782-788.

Sosnovsky, G., Li, S.W. (1985a). In the Search for New Anticancer Drugs X. N,N:N',N' -Bis(1,2-Ethanediyl) -N"- (1-oxyl-2,2,6,6-tetramethyl-4-piperidinylaminocarbonyl) Phosphoric Triamide - a New Potential anticancer Drug of High Activity and Low Toxicity. Life Sci., Vol.36, No.15, pp. 1473-1477.

Sosnovsky, G., Li, S.W. (1985b). In the Search for New Anticancer Drugs XII. Synthesis and Biological Evaluation of Spin Labeled Nitrosoureas. Life Sci., Vol.36, No.15, pp. 14791483.

Soule, B.P., Hyodo, F., Matsumoto, K., Simone, N. L., Cook, J.A., Krishna, M.C., \& Mitchell, J.B. (2007). The Chemistry and Biology of Nitroxide Radicals. Free Rad. Biol. Med. Vol.42, No.11, pp. 1632-1650.

Suy, S., Mitchell, J. B., Samuni, A., Mueller, S., \& Kasid, U. (2005). Nitroxide Tempo, a Small Molecule, Induces Apoptosis in Prostate Carcinoma Cells and Suppresses Tumor Growth in Athymic Mice. Cancer, Vol.103, No.6, pp. 1302-1313. 
Reynolds, C.P. \& Maurer, B.J. (2005). Evaluating Response to Antineoplastic Drug Combinations in Tissue Culture Models. Methods Mol. Med.,Vol.110, pp. 173-183.

Tsui, F.P., Robey, F., Engle, T.W., Ludeman, S.M., \& Zon, G. (1982). Synthesis and study of a spin-labeled cyclophosphamide analogue, 3-(1-oxyl-2,2,6,6-tetramethyl-4piperidinyl)cyclophosphamide. J. Med. Chem., Vol.25, No.9, pp. 1106-1110.

Tsutsumishita, Y., Onda, T., Okada, K., Takeda, M., Endou, H., Futaki, S., \& Niwa, M. (1998). Involvement of $\mathrm{H}_{2} \mathrm{O}_{2}$ in Cisplatin-Induced Nephrotoxicity. Biochem. Biophys. Res. Comm.,Vol.242, No.2, pp. 310-312.

Vousden, K.H. \& Prives, C. (2009). Blinded by the Light: The Growing Complexity of p53. Cell, Vol.137, No.3, pp. 413-431.

Wheate, N. J., Walker, S., Craig, G. E., \& Oun, R. (2010). The Status of Platinum Anticancer Drugs in the Clinic and in Clinical Trials. Dalton Trans., Vol.39, No.35, 8113-8127.

Wilcox, C.S. (2010). Effects of Tempol and Redox-cycling Nitroxides in Models of Oxidative Stress. Pharmacol. Ther., Vol.126, No.2, pp. 119-145.

Wondrak, G.T. (2009). Redox-Directed Cancer Therapeutics: Molecular Mechanisms and Opportunities. Antioxid. Redox Signal.,Vol.11, No.12, pp. 3013-3069. 